\title{
Micronutrient Daily Intake of Elementary School Children in Bandung as Determined by Using NAA and AAS Methods
}

\author{
E. Damastuti ${ }^{1{ }^{*}}$, W.D. Ariyani ${ }^{2}$, M. Santoso ${ }^{1}$, S. Kurniawati ${ }^{1}$ and W.Y.N. Syahfitri ${ }^{1}$ \\ ${ }^{I}$ Center for Nuclear Technology of Material and Radiometry, National Nuclear Energy Agency \\ Tamansari 71, Bandung 40132, Indonesia \\ ${ }^{2}$ Faculty of Civil and Environmental Engineering, Bandung Institute of Technology \\ Ganesha 10, Bandung 40132, Indonesia
}

\section{ARTICLE INFO}

Article history:

Received 20 November 2010

Received in Revised form 03 April 2011

Accepted 04 April 2011

Keywords:

Daily intake

Deficiency

Elementary school children

Micronutrient

\begin{abstract}
A B S T R A C T
Micronutrients in human diet are known to be among the most essential sources of nutrition, that required by the human body in small amount to maintain normal physiological function. Micronutrient malnutrition (MNM) is widespread all over the world, mostly in the developing country, where young children tend to be the most at risk of developing micronutrient deficiencies. In Indonesia, data of micronutrient status of children is limited. Therefore, the assessment of micronutrient intake of young children is needed to carry out. Food samples were taken by duplicate diet method of 19 elementary school children in Bandung and were analyzed using neutron activation analysis and atomic absorption spectrophotometry. Quality control of data analysis was assessed using SRM NIST 1548a Typical Diet. The result was giving the average daily intake of $\mathrm{Ca}, \mathrm{Cr}, \mathrm{Cu}$, $\mathrm{Fe}, \mathrm{K}, \mathrm{Mg}, \mathrm{Mn}, \mathrm{Na}$, Se and Zn were 228, 0.15, 0.57, 9.3, 929, 106, 2,1, 2314, 0.022 and $4.6 \mathrm{mg}$ /day respectively and gives $22,527,86,111,17,54,116,49$ and $63 \%$ of Recommended Dietary Allowance (RDA) values. Its generally concluded that these children are still lack of micronutrient intake, and many of them were below their recommended dietary allowances. These result were expected could be used as baseline data and reference to encourage government and related institution in making policies for public health improvement and micronutrient malnutrition solution as well.
\end{abstract}

(C) 2011 Atom Indonesia. All rights reserved

\section{INTRODUCTION}

Micronutrients in human diet are essential nutrition required by the human body in a small amount. They are needed in maintaining normal physiological function and involved in many metabolism processes. Micronutrient consist of vitamin and mineral. The mineral elements itself can be divided into macro minerals (major elements) and micro minerals (trace elements). The macro minerals, such as sodium, potassium, magnesium, calcium and phosphorus, are required by the human body in amounts greater than $100 \mathrm{mg} /$ day whereas the micro minerals, such as iron, copper, zinc, manganese, selenium and chromium, are required in amount less than $100 \mathrm{mg} /$ day [1,2]. Several of elements well recognized as essential constituents of enzymes and play a vital role in human metabolism. All the nutrient elements are primarily supplied through diet. For all the elements essential for

\footnotetext{
* Corresponding author.

E-mail address: endah_dt@batan.go.id
}

metabolism, each of them has a range of intake over which their supply is adequate for the body. However, beyond this range, deficiency and toxic effects are observed [3].

Micronutrient malnutrition (MNM) occurs when the essential elements are not sufficient to fulfil the need of body to develop and function normally [4]. Micronutrient malnutrition has many adverse effects on human health and is a concern not just because such large numbers of people are affected, but also because MNM can contribute to high rates of morbidity and even mortality [5]. It has been estimated that micronutrient deficiencies account for about $7.3 \%$ of the global burden of disease, with iron and vitamin A deficiency ranking among the 15 leading causes of the global disease burden [5]. Micronutrient malnutrition (MNM) can affect all age groups, but young children and women of reproductive age tend to be among those most at risk of developing micronutrient deficiencies. Trace element malnutrition is reported to be the biggest cause of death for children in developing countries 
and contributed to $53 \%$ of death related to infectious disease in children of age under 5 year [4]. Each micronutrient elements has its own function, describe in Table 1 . The adverse effect of deficiencies, and also toxicities of micronutrients were also listed in Table 1.

Children are human resources asset and future generation. Efforts to improve the quality of human resources begin with the fulfillment of basic human needs with primary focus on the process of growth of the child. The nutritional adequacy greatly affect intelligence and work productivity of human. School-age children represent an important and diverse target group for health and nutrition interventions. The fast growth and evolution of children permits the necessity for considering their nutritional status both qualitatively and quantitatively. The excess need for food and the great change in the life style and nutritional habits especially in the elementary school children has put them at higher risk of malnutrition [6]. Nutritional status of children as a reflection of the adequacy of nutrition, is one of the important factor to assess the growth and health status. In Indonesia, several studies of micronutrient intake has been conducted. Hayati, 2002, observed zinc intake of pregnant women in Bogor subdistrict [7] and Heikens, 2005, was observed daily intake of adult and 6-years old children of the inhabitant in Asembagus area, East Java, where hyperacid Ijen crater lake is located [8]. Nonetheless, data of micronutrient status on Indonesian children are limited, therefore it was needed to determine micronutrient daily intake of elementary school children as an assessment of children health status.

The micronutrient daily intake obtained from this activity then compared with its Recommended Dietary Allowances (RDA) values to know whether the children are having insufficience or excessive intake of micronutrients. Recommended dietary allowance (RDA) is the average daily intake level that is sufficient to meet the nutrient requirements of nearly all (97-98\%) healthy individuals in a particular life stage and gender group [14]. The RDA is intended to be used as a goal for daily intake of individuals. If insufficient scientific evidence is available to set an RDA, then an Adequate Intake (AI) may be set as a goal for individual daily intake. Adequate intake is the amount established is somewhat less firmly believed to be adequate for everyone in the demographic group. Other aspects, namely Upper Intake Level (UL), a standard reference diet to evaluate and manage risk and consumption of vitamins and minerals or usually known as excess intake level above (safe limit). Upper intake level is the maximum level of total chronic daily intake of nutrients (from all sources, including food, water

Table 1. Function, adverse effects of deficiency and excessive consumption of elements [7-15].

\begin{tabular}{|c|c|c|c|}
\hline Element & Function & $\begin{array}{l}\text { Adverse effect of } \\
\text { deficiency }\end{array}$ & $\begin{array}{c}\text { Adverse effect of } \\
\text { excessive } \\
\text { consumption } \\
\end{array}$ \\
\hline $\mathrm{Ca}$ & $\begin{array}{l}\text { Essential role in } \\
\text { blood clotting, } \\
\text { muscle } \\
\text { contraction, nerve } \\
\text { transmission, and } \\
\text { bone and tooth } \\
\text { formation }\end{array}$ & $\begin{array}{l}\text { Osteoporosis, } \\
\text { hypertension, colon } \\
\text { cancer, pramenstrual } \\
\text { syndrome, insulin } \\
\text { resistance syndrome, } \\
\text { obesity }\end{array}$ & $\begin{array}{l}\text { Kidney stones, } \\
\text { hypercalcemia, } \\
\text { milk alkali } \\
\text { syndrome and } \\
\text { renal } \\
\text { insufficiency }\end{array}$ \\
\hline $\mathrm{Cr}$ & $\begin{array}{l}\text { Helps to maintain } \\
\text { normal blood } \\
\text { glucose levels }\end{array}$ & $\begin{array}{l}\text { Impaired glucose } \\
\text { tolerance, neuropathy }\end{array}$ & $\begin{array}{l}\text { Chronic renal } \\
\text { failure }\end{array}$ \\
\hline $\mathrm{Cu}$ & $\begin{array}{l}\text { Component of } \\
\text { enzymes in iron } \\
\text { metabolism }\end{array}$ & $\begin{array}{l}\text { Normocytic, } \\
\text { hypochromic anemia, } \\
\text { leucopenia and } \\
\text { neuropenia and } \\
\text { inclusive osteoporosis } \\
\text { in children }\end{array}$ & $\begin{array}{l}\text { Gastrointestinal } \\
\text { distress, liver } \\
\text { damage }\end{array}$ \\
\hline $\mathrm{Fe}$ & $\begin{array}{l}\text { Component of } \\
\text { hemoglobin and } \\
\text { numerous } \\
\text { enzymes, prevent } \\
\text { microcytic } \\
\text { hypochromic } \\
\text { anemia }\end{array}$ & $\begin{array}{l}\text { Anemia, impaired } \\
\text { cognitive development, } \\
\text { impaired learning } \\
\text { ability }\end{array}$ & $\begin{array}{l}\text { Gastrointestinal } \\
\text { distress }\end{array}$ \\
\hline $\mathrm{K}$ & $\begin{array}{l}\text { Maintains fluid } \\
\text { volume } \\
\text { inside/outside of } \\
\text { cells and thus } \\
\text { normal cell } \\
\text { function; acts to } \\
\text { blunt the rise of } \\
\text { blood pressure in } \\
\text { response to } \\
\text { excess sodium } \\
\text { intake, and } \\
\text { decrease markers } \\
\text { of bone turnover } \\
\text { and recurrence of } \\
\text { kidney stones }\end{array}$ & Rising blood pressure. & $\begin{array}{l}\text { Hyperkalemia } \\
\text { and possibly } \\
\text { sudden death if } \\
\text { excess is } \\
\text { consume by } \\
\text { individuals with } \\
\text { chronic renal } \\
\text { insufficiency } \\
\text { (kidney disease) } \\
\text { or diabetes }\end{array}$ \\
\hline $\mathrm{Mg}$ & $\begin{array}{l}\text { Cofactor for } \\
\text { enzyme systems }\end{array}$ & $\begin{array}{l}\text { Numbness, tingling, } \\
\text { cramps, seizures, } \\
\text { personality changes, } \\
\text { abnormal heart rythms } \\
\text { and coronary spams }\end{array}$ & $\begin{array}{l}\text { Osmotic diarrhea } \\
\text { and abdominal } \\
\text { cramping }\end{array}$ \\
\hline $\mathrm{Mn}$ & $\begin{array}{l}\text { Involved in the } \\
\text { formation of bone } \\
\text { as well as in } \\
\text { enzymes } \\
\text { involved in } \\
\text { amino acid, } \\
\text { cholesterol, and } \\
\text { carbohydrate } \\
\text { metabolism }\end{array}$ & $\begin{array}{l}\text { Poor reproductive } \\
\text { performance, growth } \\
\text { retardation, abnormal } \\
\text { function of bone and } \\
\text { cartilage }\end{array}$ & $\begin{array}{l}\text { Elevated blood } \\
\text { concentration and } \\
\text { neurotoxicity }\end{array}$ \\
\hline $\mathrm{Na}$ & $\begin{array}{l}\text { Maintain fluid } \\
\text { volume outside of } \\
\text { cells and thus } \\
\text { normal cell } \\
\text { function }\end{array}$ & $\begin{array}{l}\text { Weakness, apathy, } \\
\text { nausea and cramps in } \\
\text { the muscles of the } \\
\text { extremities, confusion, } \\
\text { loss of reflexive } \\
\text { movement, } \\
\text { convulsions or even } \\
\text { coma. }\end{array}$ & $\begin{array}{l}\text { Hypertension, } \\
\text { increased risk of } \\
\text { cardiovascular } \\
\text { disease and } \\
\text { stroke }\end{array}$ \\
\hline $\mathrm{Se}$ & $\begin{array}{l}\text { Defense against } \\
\text { oxidative stress } \\
\text { and regulation of } \\
\text { thyroid hormone } \\
\text { action and the } \\
\text { reduction and } \\
\text { oxidation status } \\
\text { of vitamin C and } \\
\text { other molecules }\end{array}$ & $\begin{array}{l}\text { Develop of a form of } \\
\text { heart disease, } \\
\text { hypothyroidism, } \\
\text { weakened immune } \\
\text { system and can make } \\
\text { the body more } \\
\text { susceptible to illnesses, } \\
\text { Keshan disease. }\end{array}$ & $\begin{array}{l}\text { Hair and nail } \\
\text { brittleness and } \\
\text { loss }\end{array}$ \\
\hline $\mathrm{Zn}$ & $\begin{array}{l}\text { Component of } \\
\text { multiple enzymes } \\
\text { and proteins, } \\
\text { involved in the } \\
\text { regulation of } \\
\text { gene expression }\end{array}$ & $\begin{array}{l}\text { Growth retardation, } \\
\text { loss of appetite, } \\
\text { impaired immune } \\
\text { function, hair loss, } \\
\text { diarrhea, impotence, } \\
\text { hypogonadism and } \\
\text { mental lethargy }\end{array}$ & $\begin{array}{l}\text { Reduced copper } \\
\text { status, electrolyte } \\
\text { imbalance, } \\
\text { nausea and } \\
\text { lethargy }\end{array}$ \\
\hline
\end{tabular}


and nutritional supplements) is considered not cause adverse health risk to almost all individuals in the general population [18].

Micronutrient elements in food usually exist in a small concentration therefore high sensitivity analytical technique is needed to analyze it. Nuclear analytical technique such as neutron activation analysis (NAA), come up as an alternative analytical technique, is more efficient and satisfying than other conventional analytical techniques since NAA is known as high accuracy and sensitivity, multi-element, and non destructive technique. In this study, elemental analysis in food was done using NAA and also atomic absorption spectrometry as a complement analytical technique.

\section{EXPERIMENTAL METHODS}

\section{Sample collection and preparation for analysis}

Food samples were collected from 19 children of 5 elementary schools in Bandung city using a duplicate diet method. Figure 1 showed the sampling location map with the dot symbol as the sampling location. Duplicate diet method was a food sampling method that collect the duplicate of all the food consumed in 24 hours includes breakfast, lunch, dinner, snack, fruit, and drinks (milk, tea etc).

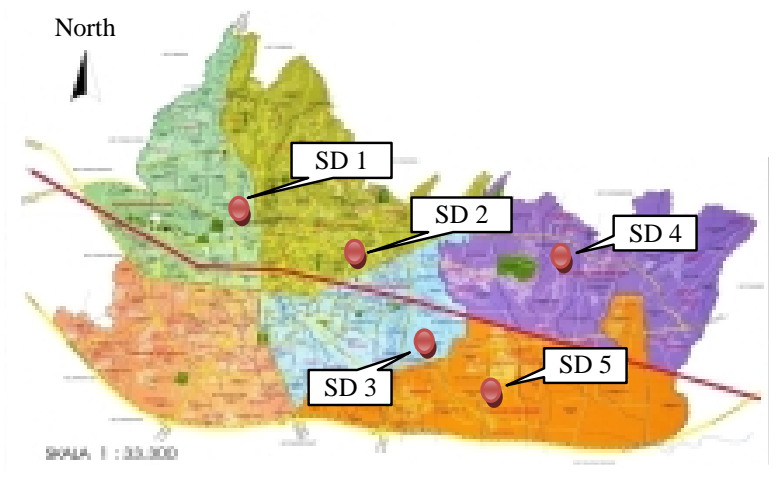

Fig. 1. Sampling locations map.

Each type of food was weighted individually (only edible portion), and then mashed together using titanium blade-blender. Food sample that has been smooth and homogeneous were weighted and placed into a small tube, then stored in the freezer until frozen. Tube which contains frozen food sample attached on freeze dryer. Freeze drying was done by the help of vacuum pump and the temperature was set at $-55^{\circ} \mathrm{C}$. Drying process took $2 \times 24$ hours until the samples dried and had constant weight. Dried samples then refined into fine powder using a teflon mortar and pestle, and then placed into polyethylene container.

\section{Analysis $\mathrm{Cr}$, Fe, Se, Zn, Na and $\mathrm{K}$ using neutron activation analysis}

As much as $0.1 \mathrm{~g}$ and $0.02 \mathrm{~g}$ powder dried samples were placed into $0.274 \mathrm{~mL}$ polyethylene vial respectively and each vial then sealed by heating. The $0.1 \mathrm{~g}$ samples were used to analyze long half-life elements such as chromium, iron, selenium and zinc, while $0.02 \mathrm{~g}$ samples were used for medium half-time elements such as sodium and potassium. For long half-life elements, $0.1 \mathrm{~g}$ samples irradiated along with SRM NIST 1548a Typical Diet and mix standard, consist of 0.1, 0,2, 10 and $20 \mu \mathrm{g}$ of Se, Cr, Zn and Fe respectively, for an hour at $15 \mathrm{MW}$ at rabbit system facilites of multipurpose reactor G.A. Siwabessy, Serpong. Samples then allowed to cool for a month then counted for $55000 \mathrm{~s}$ using gamma spectrometer with HPGe detector. The spectrum observed using Genie 2000 software at $264.66 \mathrm{keV} ; 320.08 \mathrm{keV}$; $1099.25 \mathrm{keV}$ and $1115,5 \mathrm{keV}$ for $\mathrm{Se}, \mathrm{Cr}, \mathrm{Fe}$ and $\mathrm{Zn}$ respectively. Whereas, for medium half-life elements, a $0.02 \mathrm{~g}$ samples irradiated along with SRM NIST 1548a Typical Diet and mix standard, consist $20 \mu \mathrm{g}$ of both $\mathrm{Na}$ and $\mathrm{K}$, for 15 minutes at $15 \mathrm{MW}$ at rabbit system facilites of multipurpose reactor G.A. Siwabessy, Serpong. Samples then allowed to cool for a day and then counted for 2000 s using gamma spectrometer with low resolution of HPGe detector. The spectrum observed using Genie 2000 software at $1368.6 \mathrm{keV}$ and $1524.58 \mathrm{keV}$ for $\mathrm{Na}$ and $\mathrm{K}$ respectively. Scheme of neutron activation anaysis is shown at Fig. 2.

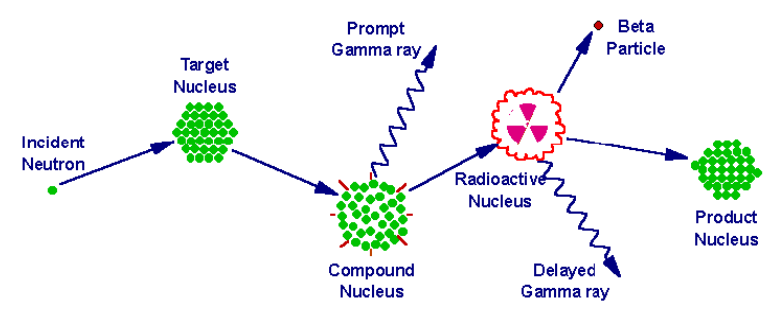

Fig. 2. Scheme of neutron activation analysis.

\section{Analysis $\mathrm{Ca}, \mathrm{Cu}, \mathrm{Mn}$ and $\mathrm{Mg}$ using atomic absorption spectrometry}

A $0,5 \mathrm{~g}$ powder food sample was dissolved by adding $2.5 \mathrm{~mL}$ aquadest, $6.5 \mathrm{~mL}$ concentrated $\mathrm{HNO}_{3}$ and $1 \mathrm{~mL}$ of $\mathrm{HClO}_{4}$ using microwave digestion for 
20 minutes at $150^{\circ} \mathrm{C}$ and power $1000 \mathrm{~W}$. The same steps were also applied to standar reference material (SRM) NIST 1548a Typical Diet. Measurement of samples were done by flame methods using atomic absorption spectrometer GBC Avanta P. The wavelength observed was $422.3 \mathrm{~nm}, 324.7 \mathrm{~nm}$, $279.5 \mathrm{~nm}$ and $285.2 \mathrm{~nm}$ for $\mathrm{Ca}, \mathrm{Cu}, \mathrm{Mn}$ and $\mathrm{Mg}$ respectively. The dissolved sample then diluted by aquadest into $25 \mathrm{~mL}$ flask and transferred to polyethylene container for determination of $\mathrm{Cu}$ and $\mathrm{Mn}$, while for $\mathrm{Ca}$ and $\mathrm{Mg}$, samples were again diluted step by step until total of dilution factor is 1250. The optimum working range for $\mathrm{Ca}, \mathrm{Cu}, \mathrm{Mn}$ and $\mathrm{Mg}$ were $1-4 \mathrm{mg} / \mathrm{kg}, 1-5 \mathrm{mg} / \mathrm{kg}, 1-3.6 \mathrm{mg} / \mathrm{kg}$ and $0.1-0.4 \mathrm{mg} / \mathrm{kg}$ respectively.

\section{Quality control and data analysis}

The standard reference material (SRM) was used as quality control assessment of data validity. The results of analysis SRM were compared with its certificate value and evaluated its accuracy and precission by $\%$ recovery and \% Coefficient Variation (CV) calculation. Net areas from Genie 2000 were used to calculate the concentrations of elements in the samples using a comparative method as well as absorbance from AAS GBC Avanta P.

\section{RESULTS AND DISCUSSION}

To assess the reliability of the result obtained and the accuracy of analitycal methods used in this activity, the standard reference material (SRM) which has similar matrix with the samples, is also analyzed in the same conditions as the samples. The results of SRM NIST 1548a Typical Diet were listed in Table 2. It is shows that the result obtained were in good agreement with certified values.

Table 2. Quality control assessment using SRM NIST 1548a Typical Diet.

\begin{tabular}{ccccc}
\hline Element & Result & $\begin{array}{c}\text { Certified } \\
\text { value }\end{array}$ & $\begin{array}{c}\% \\
\text { recovery }\end{array}$ & $\begin{array}{c}\% \\
\mathrm{CV}\end{array}$ \\
\hline $\mathrm{Ca}$ & $1907 \pm 36$ & $1967 \pm 113$ & 97 & 2 \\
$\mathrm{Cu}$ & $2.21 \pm 0.05$ & $2.32 \pm 0.16$ & 95 & 2 \\
$\mathrm{Fe}$ & $33.82 \pm 2.53$ & $35.30 \pm 3.77$ & 96 & 7 \\
$\mathrm{~K}$ & $6863 \pm 483$ & $6970 \pm 125$ & 98 & 7 \\
$\mathrm{Mg}$ & $573 \pm 14$ & $580 \pm 27$ & 99 & 2 \\
$\mathrm{Mn}$ & $5.77 \pm 0.07$ & $5.75 \pm 0.17$ & 100 & 1 \\
$\mathrm{Na}$ & $8061 \pm 239$ & $8132 \pm 942$ & 99 & 3 \\
$\mathrm{Se}$ & $0.219 \pm 0.042$ & $0.245 \pm 0.028$ & 89 & 20 \\
$\mathrm{Zn}$ & $24.1 \pm 2.4$ & $24.6 \pm 1.8$ & 98 & 10 \\
\hline
\end{tabular}

Analytical accuracy, described as \% recovery, were in the range $89-100 \%$; while analytical precision, described as \% CV were in the range $1-20 \%$. Both analytical accuracy and precision were acceptable according to AOAC guidelines [20].

The concentration of elements per unit dry weight, then converted back to its wet weight to obtain the daily intake of the elements. The micronutrient daily intake obtained then compared with the RDA values. The RDA to be used as a comparator values were taken for children aged 4-8 years and 9-13 years groups in USA, which their values were listed in Table 3. The RDA values between American and Indonesian may different. The RDA value for American (caucassian man) may not provide a realistic estimation for Indonesian because of difference typology and body mass indexes between those two races [21].

The comparison of micronutrient daily intake obtained in this activity with the RDA and UL values were described in Fig. 3a-3j. Figure 3a-3j showed that predominantly, elementary school

Table 3. Food and nutrition board references of micronutrient dietary intake $[7,8]$.

\begin{tabular}{|c|c|c|c|c|c|}
\hline Nutrient & Group & $\begin{array}{c}\text { Age } \\
\text { (year) }\end{array}$ & $\begin{array}{c}\text { RDA } \\
\text { (mg/day) }\end{array}$ & $\begin{array}{c}\mathrm{AI} \\
\text { (mg/day) }\end{array}$ & $\begin{array}{c}\mathrm{UL} \\
\text { (mg/day) }\end{array}$ \\
\hline \multirow{3}{*}{$\mathrm{Ca}$} & Children & $4 \mathrm{~s} / \mathrm{d} 8$ & - & 800 & 2500 \\
\hline & Female & $9 \mathrm{~s} / \mathrm{d} 13$ & - & 1300 & 2500 \\
\hline & Male & $9 \mathrm{~s} / \mathrm{d} 13$ & - & 1300 & 2500 \\
\hline \multirow{3}{*}{$\mathrm{Cr}$} & Children & $4 \mathrm{~s} / \mathrm{d} 8$ & - & 15 & - \\
\hline & Female & $9 \mathrm{~s} / \mathrm{d} 13$ & - & 25 & - \\
\hline & Male & $9 \mathrm{~s} / \mathrm{d} 13$ & - & 21 & - \\
\hline \multirow{3}{*}{$\mathrm{Cu}$} & Children & $4 \mathrm{~s} / \mathrm{d} 8$ & 0.44 & - & 3 \\
\hline & Female & $9 \mathrm{~s} / \mathrm{d} 13$ & 0.70 & - & 5 \\
\hline & Male & $9 \mathrm{~s} / \mathrm{d} 13$ & 0.70 & - & 5 \\
\hline \multirow{3}{*}{$\mathrm{Fe}$} & Children & $4 \mathrm{~s} / \mathrm{d} 8$ & 10 & - & 40 \\
\hline & Female & $9 \mathrm{~s} / \mathrm{d} 13$ & 8 & - & 40 \\
\hline & Male & $9 \mathrm{~s} / \mathrm{d} 13$ & 8 & - & 40 \\
\hline \multirow{3}{*}{$\mathrm{K}$} & Children & $4 \mathrm{~s} / \mathrm{d} 8$ & - & 3800 & - \\
\hline & Female & $9 \mathrm{~s} / \mathrm{d} 13$ & - & 4500 & - \\
\hline & Male & $9 \mathrm{~s} / \mathrm{d} 13$ & - & 4500 & - \\
\hline \multirow{3}{*}{$\mathrm{Mg}$} & Children & $4 \mathrm{~s} / \mathrm{d} 8$ & 130 & - & 350 \\
\hline & Female & $9 \mathrm{~s} / \mathrm{d} 13$ & 240 & - & 350 \\
\hline & Male & $9 \mathrm{~s} / \mathrm{d} 13$ & 240 & - & 350 \\
\hline \multirow{2}{*}{$\mathrm{Mn}$} & $\begin{array}{l}\text { Children } \\
\text { Female }\end{array}$ & $\begin{array}{c}4 \mathrm{~s} / \mathrm{d} 8 \\
9 \mathrm{~s} / \mathrm{d} 13\end{array}$ & - & $\begin{array}{l}1.5 \\
1.9\end{array}$ & $\begin{array}{l}3 \\
6\end{array}$ \\
\hline & Male & $9 \mathrm{~s} / \mathrm{d} 13$ & - & 1.6 & 6 \\
\hline \multirow{2}{*}{$\mathrm{Na}$} & $\begin{array}{l}\text { Children } \\
\text { Female }\end{array}$ & $\begin{array}{c}4 \mathrm{~s} / \mathrm{d} 8 \\
9 \mathrm{~s} / \mathrm{d} 13\end{array}$ & - & $\begin{array}{l}1200 \\
1500\end{array}$ & $\begin{array}{l}1900 \\
2200\end{array}$ \\
\hline & Male & $9 \mathrm{~s} / \mathrm{d} 13$ & - & 1500 & 2200 \\
\hline \multirow[b]{2}{*}{$\mathrm{Se}$} & Children & $\begin{array}{c}4 \mathrm{~s} / \mathrm{d} 8 \\
9 \mathrm{~s} / \mathrm{d} 13\end{array}$ & $\begin{array}{l}0.030 \\
0.040\end{array}$ & - & $\begin{array}{l}0.15 \\
0.28\end{array}$ \\
\hline & Female & $9 \mathrm{~s} / \mathrm{d} 13$ & 0.040 & - & $\begin{array}{l}0.20 \\
0.28\end{array}$ \\
\hline \multirow{3}{*}{$\mathrm{Zn}$} & Children & $4 \mathrm{~s} / \mathrm{d} 8$ & 5 & - & 12 \\
\hline & Female & $9 \mathrm{~s} / \mathrm{d} 13$ & 8 & - & 23 \\
\hline & Male & $9 \mathrm{~s} / \mathrm{d} 13$ & 8 & - & 23 \\
\hline
\end{tabular}

Note: RDA is the average daily intake level that is sufficient to meet the nutrient requirements of nearly all (97-98 \%) healthy individuals in a particular life stage and gender group. AI is the amount established is somewhat less firmly believed to be adequate for everyone in the demographic group. UL is the maximum level of total chronic daily intake of nutrients considered not cause adverse health risk to almost all individuals in the general population. 


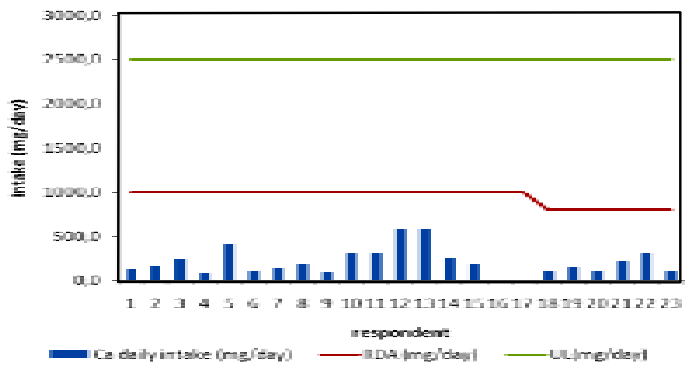

(a)

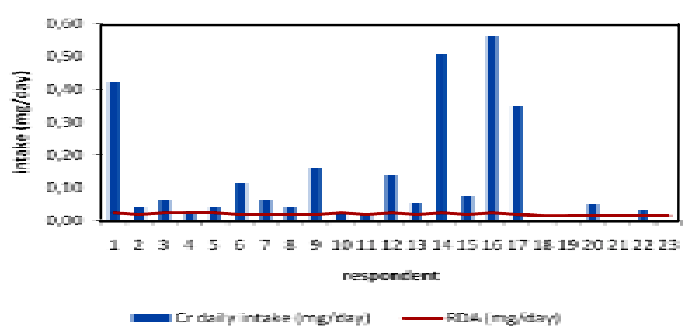

(b)

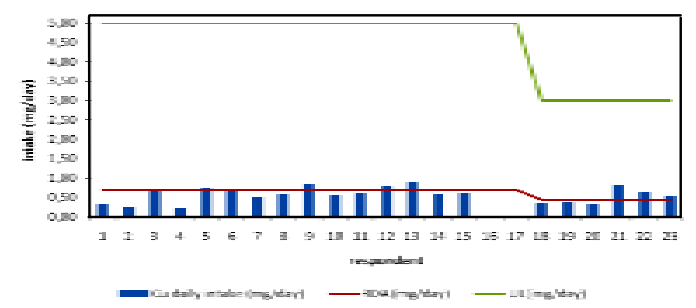

(c)

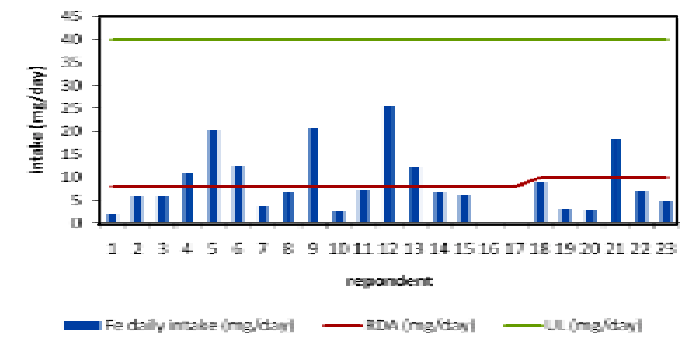

(d)

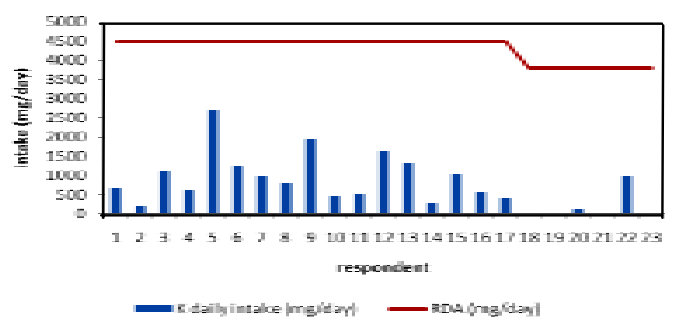

(e)

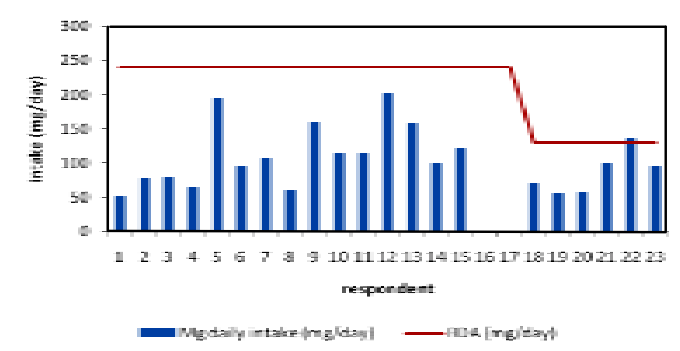

(f)

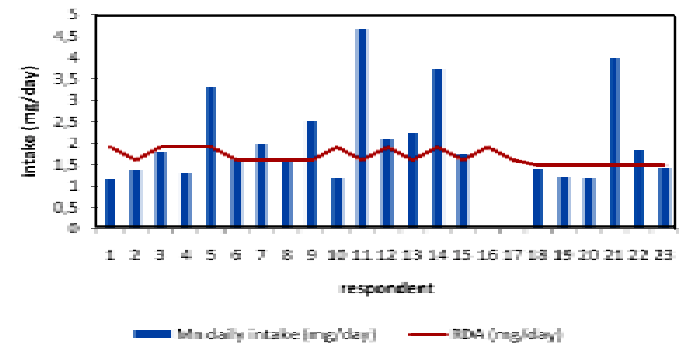

(g)

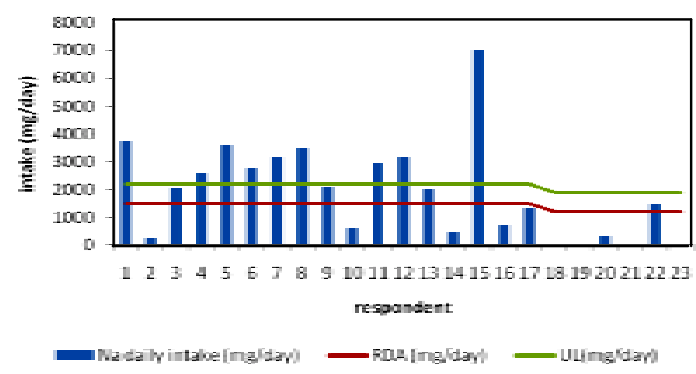

(h)

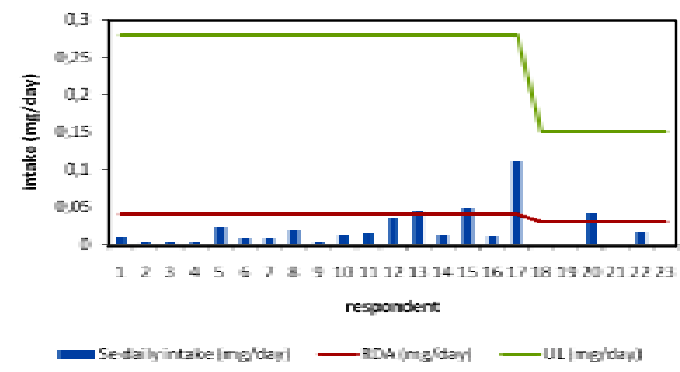

(i)

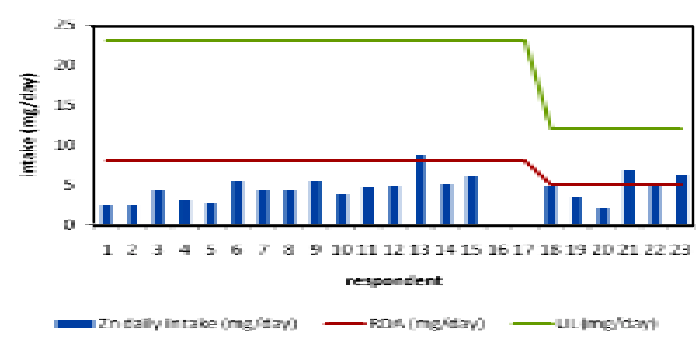

(j)

Notes: RDA (mg/day) [7,8], UL (mg/day) [7,8]

Fig. 3. Daily intake of (a) $\mathrm{Ca}$, (b) $\mathrm{Cr}$, (c) $\mathrm{Cu}$, (d) $\mathrm{Fe}$, (e) $\mathrm{K}$, (f) $\mathrm{Mg}$, (g) Mn, (h) Na, (i) Se and (j) Zn of elementary school children in Bandung city.

children observed are still lack of micronutrient. Chromium, manganese and sodium are exception. Calcium is one of micronutrient where all children in this research are inadequacy of it. The average daily intake of calcium is $228 \mathrm{mg} /$ day and only gives about $22 \%$ of RDA as seen in Fig. 3a. Sources of calcium are known from milk, dairy products, broccoli and spinach. Insufficient calcium intake where caused by lack consumption of milk or dairy products. Almost a half of the children did not 
consume any milk or dairy products on the days when sampling taken, whereas adequate calcium intake from milk and milk products in childhood and adolescence is among the determinants for attainment of maximum bone mass [22].

Deficiency are observed also for magnesium, potassium, zinc, selenium, iron, and copper where the average daily intake of $\mathrm{Cu}, \mathrm{Fe}, \mathrm{K}, \mathrm{Mg}$, Se and $\mathrm{Zn}$ are $0.57,9.29,929,106,0.022$ and $4.6 \mathrm{mg} /$ day respectively and gives $86,111,17,54,49$ and $63 \%$ of RDA as seen in Fig. 3a- $3 \mathrm{f}$ and $3 \mathrm{i}-3 \mathrm{j}$. Though average daily intake of iron were exceded RDA value, almost $67 \%$ of the children have iron intake below RDA as can be seen in Fig. 3d. It seems the average value of iron intake were contributed by some children who have excess iron intake, probably come from leaching of cooking utensils made from iron.

Slight excessive consumption were occured on manganese intake, where the average daily intake of Mn, $2.1 \mathrm{mg} /$ day, gives $116 \%$ of RDA. Figure $3 \mathrm{~g}$ showed that predominantly manganese intake were exceeded the RDA value. This result were in good agreement with Carmen 2009 that Mn deficiency in human is rare because widely distribution of $\mathrm{Mn}$ in food would make variation and balance food consumptions were suffice the amount of $\mathrm{Mn}$ needed by human body [23].

Significant excessive consumptions were occured on sodium and chromium. Almost all of the children have chromium intake exceed the RDA and some of the children were extremely have high chromium intake as can be seen in Figure $3 b$. The average chromium intake was $0.147 \mathrm{mg} /$ day, 5 times greater than RDA, High chromium intake known has adverse effect on health, but unfortunately, the upper intake level is not established yet, then it cannot be determined precisely whether this high chromium intake posses adverse effect on health. The content of chromium in foods known can subtstantially affected by agricultural and manufacturing processes [24]. Sodium intake of elementary school children obtained in this study were exceed RDA value even upper intake level as seen in Fig. 3h. The average sodium intake was $2314 \mathrm{mg} /$ day and gives $123 \%$ of RDA. The high levels of sodium consumption caused by dietary pattern which consume lots of processed foods, instant, canned or fast foods. These kind of foods have high sodium content, not only from salt but comes from the flavor enhancer or preservative substance which is currently widely used by the food industry. Sodium intakes exceeded UL value are become a concern because it posses adverse effects on health such as increasing blood pressure.
Figure 4 showed the differences in micronutrient intake in different age groups. Human needs of micronutrient intake will vary according to ages. Older children would need more nutrients. In this study, elementary school age children were divided into 2 age groups consist of 4-8 years and 9-13 years in accordance with the classification used by the Food and Nutrition Board [9,10]. From the results obtained that the intake of $\mathrm{Fe}, \mathrm{Cr}, \mathrm{Na}, \mathrm{K}$, $\mathrm{Ca}$ and $\mathrm{Mn}$ in the age group 9-13 years was higher than children with ages 4-8 years. Chromium intake in children aged 9-13 years is four times greater than the intake of children aged 4-8 years while sodium intake $i$ in 9-13 year old childrens 3 times greater than 4-8 years old children.
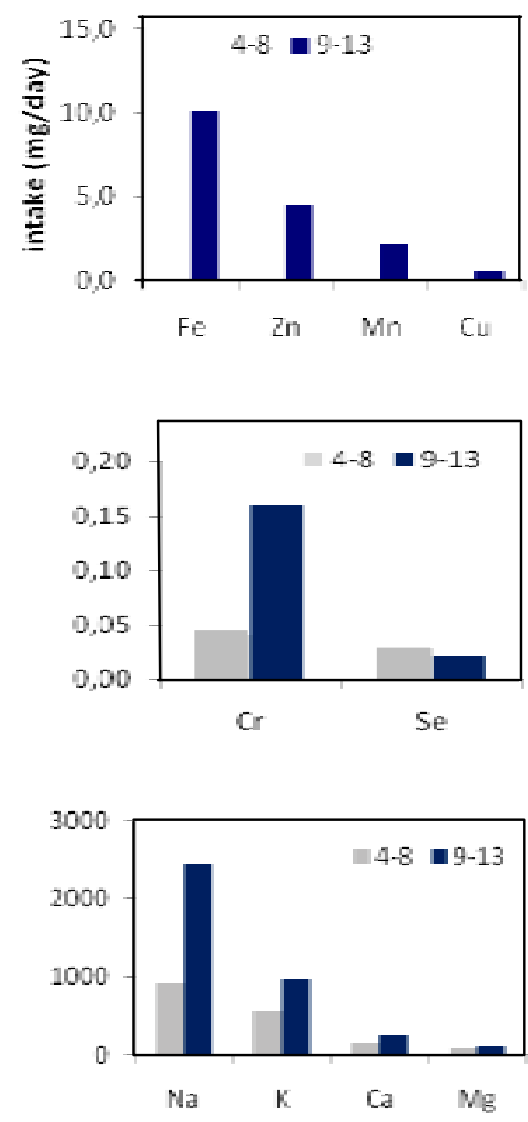

Fig. 4. Micronutrient daily intake of children with difference age group.

Micronutrient intake in 9-12 years males and females are presented in Fig. 5. Figure 5 showed that the level of micronutrient intake in 9-12 years males and females are not so different. This shows that both males and females on elementary school age have a similar diet, considering that at the elementary school age children both males and females have similar levels of activity, so the calories needed per day will be the same. The result 
obtained were in good agreement with other research in Pakistan, R. Mian 2009, that there was no significant association between nutritional status and gender in school age children [25].
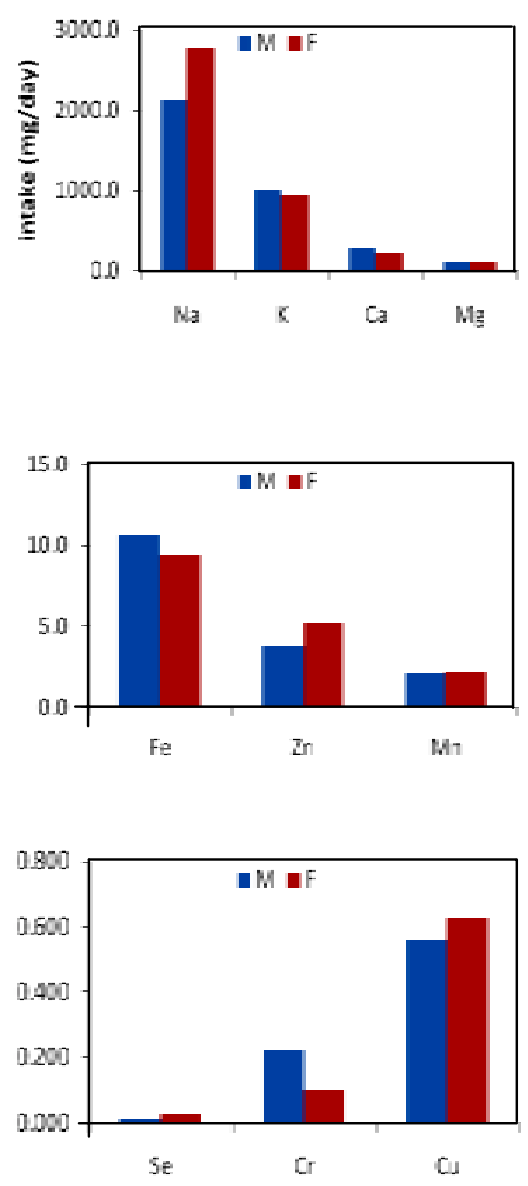

Fig. 5. Micronutrient daily intake of 9 - 12 years old males (M) and females $(\mathrm{F})$.

The relationship between micronutrient intakes with body weight are presented in Fig. 6 . It is shown that there is no correlation between micronutrient intake with body weight, except for sodium. From the Fig. 6, it can be seen that the higher the sodium intake the more increase of body weight. This is consistent with Venezia et al, 2010 suggesting that there is a strong correlation between high levels of sodium consumption with obesity [26]. It is known that high sodium in the blood will increase water retention resulting thirsty feeling. Trends beverage consumptions among children and adolescents suggests that soft drinks, which high in calories, may be replacing more nutritious beverages such as milk and fruit juices [11]. And it worsens since their coupled with the current diet by consume more fast food where high of fat content.
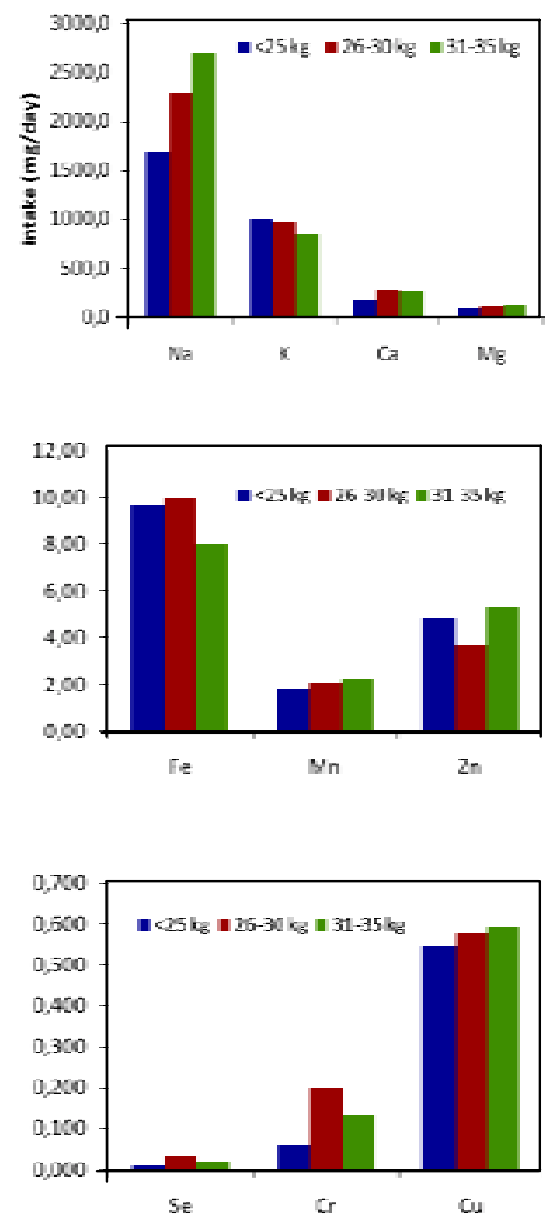

Fig. 6. Micronutrient daily intake of children aged $7-12$ years with difference body weight.

Figure 7 showed the relationship between micronutrient intake status with the status of elementary school standard, and there is no strong correlation between school standards with micronutrient intake. In general, diets of elementary school children are not strongly influenced by gender, body weight or school standards. It appears that elementary school children in the city of Bandung have a similar diet. In general, dietary patterns of primary school children in the city of Bandung from the results of questionnaires can be seen in Fig. 8.

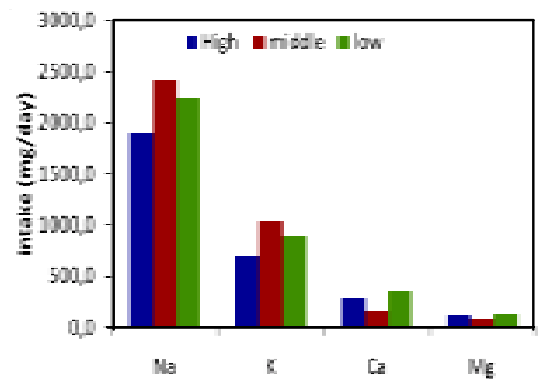



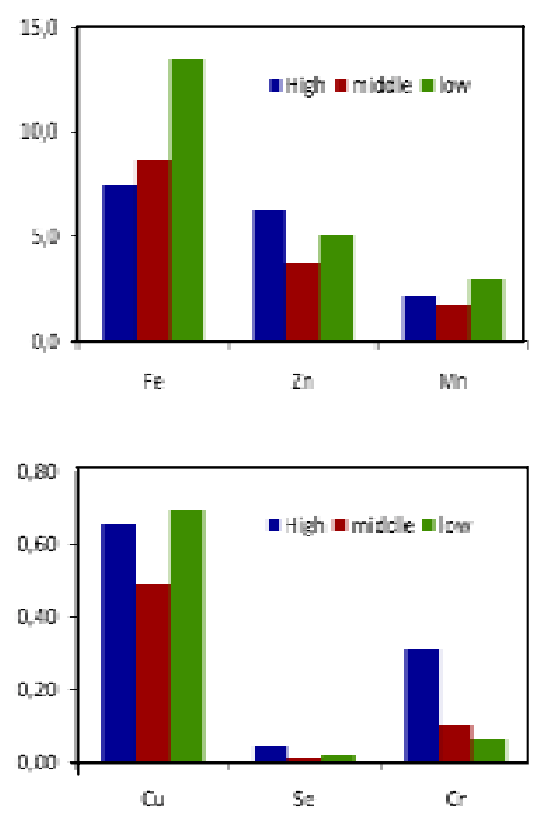

Fig. 7. Micronutrient daily intake of children from difference standard of school.

A dietary pattern of children in Bandung, described in Fig. 8, showed that most children daily diet mainly consists of carbohydrates followed by protein. Compared with the Indonesian dietary guidelines, children may not consume enough of vegetables and fruits and consume too many carbohydrates. Healthy diet is a balanced diet with a varied menu with the largest consumption is a source of carbohydrates followed by vegetables and fruits, as shown in Fig. 8. It also found that about 7 of 19 elementary school children from this research were skipping meals, mainly at dinner. As mentioned by Kim, 2005 that poor dietary patterns, such as skipping meals, placing nourished foods with low nutrient dense foods, freequent sancking and biased eating habits can contribute to inadequate nutrition during childhood [28]. The lack of micronutrient intake in children should receive serious attention, especially for iron and zinc deficiencies since they were ones of main focus of WHO lately. Malnutrition in childhood will not only impair cognitive and behavioral development leading to educational failure but also impair the capacity for physical work later in adulthood and chronic diseases caused by malnutrition in childhood will progress in adulthood [25]. With variations of food in adequate amount and not skipping meals were expected can fulfil the amount of micronutrient needed by the body. Excessive sodium intake could be avoided by reducing salt, taking free or low sodium foods instead of high sodium foods, and consume processed, instant, canned or fast foods as a treat. These results are expected to be a science-based reference or as a baseline data needed in decision-making or policies related to public health improvement and micronutrient malnutrition solution as well.

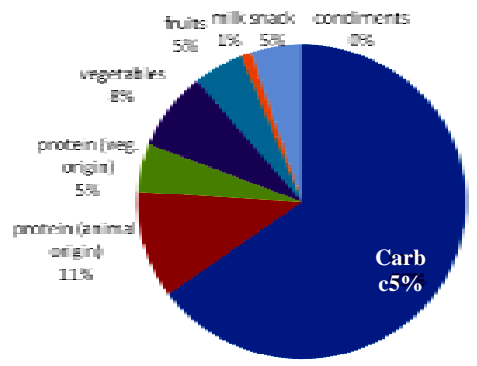

(a)

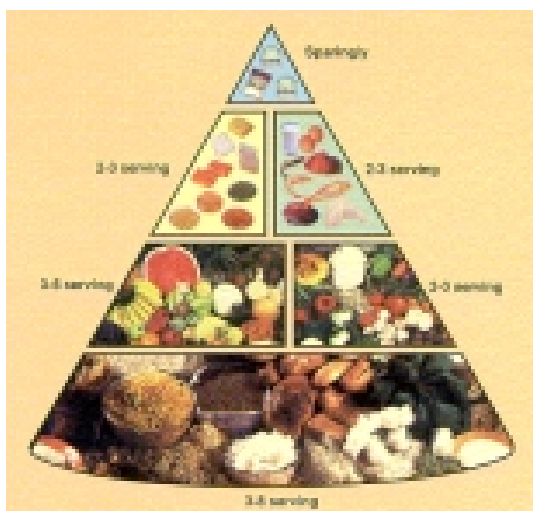

(b)

Fig. 8. (a) Dietary pattern of elementary school children in Bandung, (b) Indonesian dietary guidelines [27].

\section{CONCLUSION}

Micronutrients intake of elementary school children in Bandung city were assessed. NAA and AAS as used analytical methods gave satisfied results on determining micronutrients content in children diets. Deficiency are observed in $\mathrm{Ca}, \mathrm{Cu}$, $\mathrm{K}, \mathrm{Mg}, \mathrm{Se}$ and $\mathrm{Zn}$ with average daily intake of elementary school children were only fulfil 22,86 , $17,54,49$ and $63 \%$ of their RDA values respectively. Iron is considering to be deficiency even though its average daily intake were exceed its RDA values since $67 \%$ of the children were having iron intake below the RDA values. Excessive consumption were occur in $\mathrm{Cr}$ and $\mathrm{Na}$ with average $\mathrm{Cr}$ daily intake are 5 fold from its RDA and $\mathrm{Na}$ intake were $123 \%$ of its RDA. Elementary school children in Bandung city were suffering from deficiency as well as excessive intake of micronutrients. Control and betterment of the 
dietary intake of children should become a concern for governance and public as well in order to the formation of better quality of next human resources.

\section{ACKNOWLEDGEMENTS}

The authors would like to extends our thanks to Prof. Dr. Aang Hanafiah for the time and guidance in writing this paper, Dr. Katharina Oginawati for its research cooperation, Diah Dwiana, Natalia Adventini for helping in analysis processes and also other staffs of Radiometry Analysis Technique working group for the team work all along

\section{REFERENCES}

1. E.O. Akpanyung, Pakistan J. Nutr. 5 (2006) 198.

2. C.G. Fraga, Mol. Aspects Med. 26 (2005) 235.

3. V. Singh and A.N. Garg, Food Chem. 94 (2006) 81.

4. N.K. Mohammed and N.M. Spyrou, Appl. Radiat. Isot. 67 (2009) 480.

5. WHO, FAO, Guidelines on Food Fortification With Micronutrients (2006).

6. S.J. Pourhashemi, M.G. Motlagh, G.R.J. Khaniki and B. Golestan, Pakistan J. Nutr. 6 (2007) 687.

7. A.W. Hayati, Hardinsyah and Rimbawan, $\begin{array}{llll}\text { Forum Pascasarjana } & 25 & \text { (2002) } & 233\end{array}$ (in Indonesia).

8. A. Heiken, B. Widianarko, I.C. Dewi, J.L.M. de Boer, W. Seinen and K. van Leeuwen, Environ. Geochem. Health 27 (2005) 475.

9. Anonymous, Dietary Reference Intake: Recommended Intakes for Individual, Elements, Food and Nutrition Board, Institute of Medicine, National Academies, USA (2004).

10. Anonymous, Dietary Reference Intake: Recommended Intakes for Individual, Electrolytes and Water, Food and Nutrition Board, Institute of Medicine, National Academies, USA (2004).

11. T.A. Nicklas, J. Am. Coll. Nutr. 22 (2003) 340.
12. Anonymous, Dietary Supplement Fact Sheet: Chromium. http://ods.od.nih.gov. Retrieved in August (2010).

13. Anonymous, Dietary Supplement Fact Sheet: Magnesium. http://ods.od.nih.gov. Retrieved in August (2010).

14. S.B. Goldhaber, Regul. Toxicol. Pharmacol. 38 (2003) 232.

15. Anonymous, Dietary Supplement Fact Sheet: Zinc. http://ods.od.nih.gov. Retrieved in August (2010).

16. Anonymous, Dietary Supplement Fact Sheet: Selenium. http://ods.od.nih.gov. Retrieved in August (2010).

17. P.C. Onianwa, A.O. Adeyemo, O.E. Idowu and E.E. Ogabiela, Food Chem. 72 (2001) 89.

18. R.J. Fletcher et al., Risk-Benefit Analysis of Micronutrients, Food Chem, Toxicol. 42 (2004) 1903.

19. M.D. Glascock, Overview of Neutron Activation Analysis. http://archaeometry.miss ouri.edu/naa_overview.html. Retrieved in March (2009).

20. Anonymous, Guidelines for Single Laboratory Validation, AOAC International (2002).

21. P. Akhter, M. Akram, S.D. Orfi and N. Ahmad, Nutrition 18 (2002) 274.

22. H. Grunberg, K. Mitt and M. Thetloff, Scand. J. Nutr. 41 (1997) 18.

23. C.V. Carmen and B. Paula, Food Chem. 117 (2009) 757.

24. M. Krzysik, H. Grajeta and A. Prescha, Food Chem. 107 (2008) 208.

25. R.M.A. Mian, M. Ali, P.A. Ferroniand and P. Underwood, Pakistan J. Nutr. 1 (2002) 121.

26. A. Venezia et al., European J. Clin. Nutr. (2010) 1.

27. Anonymous, Indonesian Dietary Guidelines. http://www.gizi.net. Retrieved in March (2008).

28. S.H. Kim and C.L. Keen, Nutr. Res. 22 (2002) 433. 